\title{
THE IMPACT OF CLIMATE ARIDIZATION ON OAK STANDS IN THE REPUBLIC OF MOLDOVA (CASE STUDY)
}

\author{
Maria Nedealcov ${ }^{1}$, Ala Donica ${ }^{2}$, Nicolae Grigoraș²
}

Key words: climate change, oaks, ecoclimatic indices, evaluation.

\begin{abstract}
The forests of the Republic of Moldova are composed predominantly by mesophilous deciduous tree species, the most valuable specie are oaks, located at the limit of their natural area. The growth and survival of forests, especially in the peripheral and transition areas of ecosystems, such as the oaks stands of country, also depend on the variety of the thermal and pluviometric regime, which has changed over the last decades in the context of climate aridization. The estimation of the mesophilic tree species exposure to regional climate aridization is shown by the simultaneous use of a set of eco-metric indices: Forest Aridity Index (FAI), De Martonne Index (IM), Ellenberg Coefficient (EQ), and Beech Tolerance Index (Q $\mathrm{Q}_{\mathrm{BTI}}$ ). For areas occupied by oaks (within 2 major natural reserves from central part of Moldova), have been indicated FAI values equal to 6.5-7.5; IM values between

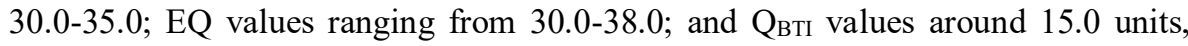
favourable for the mesophilic oak forests development. This fact indicates that during the vegetation period of mesophilic trees, in the central part of the Republic of Moldova, in more arid conditions of development, through modification of oak sensitivity to the water deficit, changes will occur in the compositional structure of ecosystems and the chorology of species. The study results are of particular interest in the sustainable management of the national forestry sector.
\end{abstract}

\section{Introduction}

The relationships between climatic conditions and vegetation have been addressed in numerous global and regional studies so far, in particular, in the context of current climate change, modifications that will change the zonal and altitudinal distribution of different species. The forests of the Republic of Moldova are predominant by deciduous species $(97.8 \%)$, of which the oaks are dominant $39.6 \%$, followed by acacia $-36.1 \%$, ash $-4.6 \%$, hornbeam $-2.6 \%$, poplars $-1.6 \%$,

${ }^{1}$ Laboratory of Climatology and Environmental Risks, Institute of Ecology and Geography, the Republic of Moldova

${ }^{2}$ Research group "Forest Ecobiochemistry", Institute of Ecology and Geography, the Republic of Moldova. 
other deciduous species $-13.4 \%$ and softwoods $-2.1 \%$. The most valuable tree stands of the forest fund are the oaks; from their total area - $27 \%$ come from the seed and $73 \%$ from the shoots, which also influences their productivity, thus $43 \%$ being of superior productivity and $57 \%$ of inferior productivity. The process of acacia expanding areas, in the last period, economically convenient, has reduced the importance of indigenous species, some of them being at their area' limits, like oak, beech, maple, etc. (Raport privind starea sectorului forestier..., 2011).

According to the Strategy in the field of climate change and the possible impact on the forest sector (Strategia de adaptare la schimbările climatice..., 2014), the most vulnerable areas in the Republic of Moldova will be: the south (where already is the lowest level of afforestation -7.7\%) and, partly, the center (where at present is the largest area covered by forests, about $14.5 \%$ of the total geographical area). It is remind that the central and eastern mesophilic forests from the North and the center of our country are at the South-Eastern limit of its natural area (Fig. 1) and the dry years from the beginning of the third millennium may lead to a diminution of mesophilous forests (Fagus sylvatica, Quercus petraea, Quercus robur), which will tend to retreat to the center of the area (central Europe), in favor of the thermophilous forests with Quercus pubescens from the South of the country (Ecosistemele: evaluarea vulnerabilităților..., 2010).

Climate change is associated with numerous and complex adverse effects on environmental components, including forest ecosystems. It is expected that the mesophilic deciduous forests from continental temperate zone will develop under conditions of annual average temperatures increase with $3-4^{0} \mathrm{C}$, and in some areas, even with $4-4,5^{\circ} \mathrm{C}$ (Central Europe and the Black Sea region); the average annual values of precipitation will increase by $10 \%$, especially for the winter period, while in summer, large areas, will be attested reduction of precipitation, even to $-10 \%$ (Impacts of Climate Change on European Forests and Options for Adaptation, 2008).

For the forests at the natural distribution limit (the xeric limit) from silvosteppe, the availability of water will cause changes in the structure and functioning of the forest ecosystem, and through relatively small changes in the soil moisture balance will lead to major ecological changes - species corology, diminution of ecosystem services, etc., (Mátyás C. et.al. 2014). Therefore, the purpose of this paper is to determine the potential impact of climate aridization on native species, ecosystem edifying - oak trees (Quercus robur, Q. petraea, Q.pubescens), identifying areas of forests vulnerability to future climate change (using a set of ecoclimate indices). Researches, related to adaptation of tree native species to future climatic conditions, are recommended also at national level, through inclusion of forestry problems in national environmental strategies 
(Republica Moldova - Notă de politici forestiere, 2014; Strategia Republicii Moldova de adaptare la schimbarea climei..., 2014 etc.).

\section{Methods of study}

The research areas are from the Central part of the country and include the

"Plaiul Fagului" Nature Reserve and the "Codrii" Nature Reserve, areas larger than 5000 ha each, which include forest ecosystems dominated by mesophile, European species. To determine the complex relationship between climate conditions of studied areas and distribution of oaks, study was based on a set of climatic indices: Forest Aridity Index - FAI; DeMartonne Index - IM; Ellenberg Quotient - EQ and Beech tolerance index - $\mathrm{Q}_{\mathrm{BTI}}$.

Forestrv Aridity Index (FAI) is used as an index that can rendering, also, the favorability of climatic conditions to beech forests. It was calculated according formula:

$$
F A I=100 *\left[\left(T_{\mathrm{VII}-\mathrm{VIII}}\right) /\left(\mathrm{P}_{\mathrm{V}-\mathrm{VII}}+P_{\mathrm{VII}-\mathrm{VIII}}\right)\right]
$$

where $\mathrm{T}_{\mathrm{VII}-\mathrm{VIII}}$ is the mean temperature of the July and August, $\mathrm{P}_{\mathrm{V}-\mathrm{VII}}$ represents the precipitation sum of the period May-July and $\mathrm{P}_{\mathrm{VII}-\mathrm{VIII}}$ is the precipitations of July and August.

FAI, developed by Führer $(2010,2011)$ set for Central Europe the beech favorability threshold at a FAI value of less than 4.75 or below; hornbeam-oak climate - FAI value between 4.75 and 6.0 ; sessile oak - Turkey oak climate the FAI values between 6.0 and 7.25; and for forest-steppe climate - FAI with higher values.

De Martonne aridity index (IM) can be calculated both for annual and monthly values. For annual values, it is used the following formula:

$$
\mathrm{IM}=\mathrm{P} /(\mathrm{T}+10)
$$

where $\mathrm{P}$ - the annual amount of precipitation, $\mathrm{T}$ - the mean annual temperature, 10 - a coefficient that is added in order to obtain positive values (De Martonne, 1926).

The values of this index can also render the influence of the climate conditions on vegetal association or forest vulnerability zones (Integrated Drought Management Program, 2014).

Ellenberg Quotient (EQ) is calculated according to the formula:

$$
\mathrm{EQ}=(\mathrm{Tw} / \mathrm{P}) * 1000
$$

where Tw - temperature of the warmest month of the year, $\mathrm{P}$ - annual precipitations 
(Ellenberg H., 1988). Ellenberg's indices are defined by the author himself as a useful paradigm to summarize interactions between plants and environment, recognizing to each species a role as biological indicator.

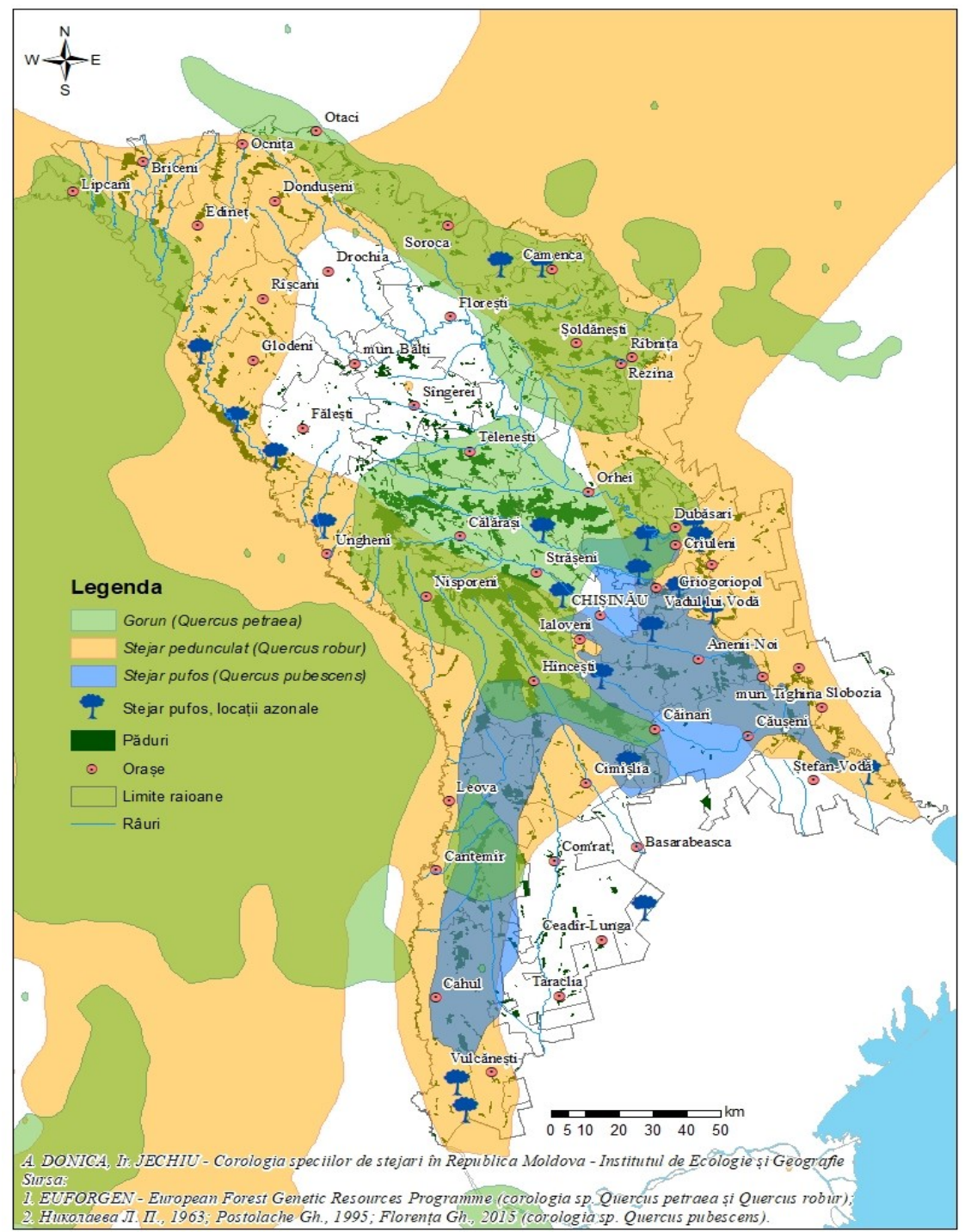

Fig. 1. Chorology of oak species within the Republic of Moldova territory (Donica et. al., 2019).

According to studies about beech forest distributional range, a ratio below 20 
indicates a pure beech climate in the "prevailing range", between 20 and 30, the competitive vigor of the species gradually decreases in this "transition range", and in the "exclusion range" over 30 beech presence is strongly reduced (Jahn G., 1991). Also, the EQ scale exhibits a wide range for forest type characterization, varying from the pure beech zone $(\mathrm{EQ} \leq 20)$ through oak-hornbeam woodlands $(E Q=20-30)$ and mesic oak forests $(E Q=30-40)$ to dry oak forests $(E Q>40)-$ (Ellenberg H., 1996).

Beech tolerance index $\left(\mathrm{Q}_{\text {вті }}\right)$ was introduced based on the weighted spring, summer precipitation and mean summer temperatures:

$$
\mathrm{Q}_{\mathrm{BTI}}=\frac{0.2 * \mathrm{P}_{\mathrm{III}}+0.5 * \mathrm{P}_{\mathrm{IV}}+\mathbf{P}_{\mathrm{V}}+\mathbf{P}_{\mathrm{VI}}+\mathbf{P}_{\mathrm{VII}}+0.8 * \mathrm{P}_{\mathrm{VIII}}}{\left(\mathrm{T}_{\mathrm{VI}}+\mathrm{T}_{\mathrm{VII}}+\mathrm{T}_{\mathrm{VIII}} / 3\right.}
$$

where: $\mathrm{P}_{\mathrm{III}}$ :precipitation in March; $\mathrm{P}_{\mathrm{IV}}$ :precipitation in April; $\mathrm{P}_{\mathrm{V}}$ :precipitation in May; $\mathrm{P}_{\mathrm{VI}}$ :precipitation in June; $\mathrm{P}_{\mathrm{VII}}$ :precipitation in July; $\mathrm{P}_{\mathrm{VIII}}$ :precipitation in August; $\mathrm{T}_{\mathrm{VI}}$ :mean temperature in June; $\mathrm{T}_{\mathrm{VII}}$ :mean temperature in July; $\mathrm{T}_{\mathrm{VIII}}$ : mean temperature in August.

The value of the $\mathrm{Q}_{\text {втI }}$ related to drought tolerance limit of beech is about 10.8 as an average, for studies in Hungary (Rasztovits E., 2011).

Temporal change of these indices for 1960-2017 in Republic of Moldova was calculated based on 17 meteorological station data (from State Hydrometeorological Service), using Statgraphics Centurion XVI Programme, ArcGIS program, with the Spatial Analyst extension.

\section{Results and discussions}

The focus on future projections, regarding the impact of climate change on the forestry sector, is on the meteorological drought. The meteorological drought is specific to the different regions, being in full progress also in Moldova, its effects being felt by the air temperature increasing and the precipitation reducing. The vulnerability zones of forest ecosystems to drought can be recovered by using the De Martonne Aridity Index.

From the analyzes carried out, it is determined that in an annual aspect, according to the values of the DeMartonne Index - values above the limit of 30, the given area is characterized by specific climatic conditions of the forest steppe area, from the central part of the country. At the same time, starting with the $80 \mathrm{~s}$ of the 20th century, there is a decrease of the values, largely determined by the increase of the thermal background (Nedealcov M. et. al. 2017).

In seasonal aspect, the IM values during the years 1891-2016, vary within the limits 10-30, which shows that summers in the central part of the country are characterized by climatic conditions similar to the steppe area. From all the 
aforementioned period, subject to the study, only in 4 years $(1912,1914,1933$, 1948), according to IM, have been established climatic conditions specific to the silvostepe area. Similarly, as in the case of annual values, the seasonal ones register a decrease, starting with the 80 s of the previous century.

The same temporal legalities are retained in the monthly aspect. Only with one difference, that the IM values are closer to the limit 10, the boundary line between the climatic conditions characteristic of dry and semi-desert steppes.

In addition to the fact that the DeMartonne index is used in climate regions and characterizes the climatic conditions of certain natural areas, it also has the role of highlighting the degree of aridity of the territory. According to the value of this index, the areas of vulnerability of forests can be identified, with particularities distinct from each one (Integrated Drought Management Programme, 2014).

If we compare the obtained data with those of the specialized literature, then it is indicated that for the areas occupied by oak stands have been indicated IM values between 30.0-33.0, so that the part of NE, E, SW of natural reserves have favorable climatic conditions to the oaks development, in the rest of the territory other species are developing - hornbeam, ash, linden,maple, etc., (Fig. 2b).

Based on the temporal aspects of the IM, in which the decreases of the values of this index are evident, starting with the $80 \mathrm{~s}$ of the XX century, we deduce that, in the future, there is a risk that the forest ecosystems investigated will pass from the area of medium vulnerability (disturbances of the moisture in some years), to the area of high vulnerability (lasting disturbances of the moisture).

Scientific researches in domain have shown a direct dependence between the ecophysiological processes of the trees and the meteorological parameters, especially in the case of tree supply with water in the tree growing period (May to July), with major influences in critical months (July and August), which have a decisive impact on the growth and vitality of trees, and production of organic matter in forests (relationships reported by FAI index). For temperate forests, the higher FAI's values indicate, for the critical period of the forest species, more dry and more arid conditions of development, and the lower FAI's values - wetter and warmer condition in growth period (Fuhrer E., et al., 2011).

For the territory of the Republic of Moldova FAI index constitutes 5.70 for the northern region; 8.35 for the central region and 10.75 for the southern region of the country, so that the forest ecosystems in the south and the center of the country are the most affected by the climate drying phenomenon. In evolutionary aspect the highest values of the FAI are registered in the central and southern part of the country and the years in which the values are the most pronounced, were so-called "dry years": 2000, 2003, 2007, 2009, 2015. It has been found that geographical latitude and absolute altitude are the main physico-geographical factors that influence the distribution of this index within country (Nedealcov M. et. al., 2016). 
For the investigated areas, Quercus robur and Q.petraea develop in climatic conditions, expressed by the following values of the FAI: "Plaiul Fagului" Nature Reserve - 6,8-8,6; and the "Codrii" Nature Reserve - 6,8-8,4 (Fig. 2a), which is not far from the average of this index, for the central region $(8,35)$ and which indicates climatic conditions, during the growth period, favorable to mesophilic species development, with a tendency towards drought-tolerant species.

Climate change tends to induce various changes in the spectrum of ecological groups. It is possible to increase the percentage of xerophytic and meso-xerophyte species due to the decrease of meso- hygrophilous and hygrophilous. It is also possible to widen the spreading area of the southern and southeastern elements (Quercus pubescens) due to the decrease of the northern and western elements (Quercus robur and Q,petraea) and to continue the process of grass cover ruderalization in the forests (Postolache Gh., 2000). The degree of correspondence of the tree-building species composition for a given area can be shown by calculating the Ellenberg coefficient. For the territory of the country, in general, the statistical calculation regarding the multiannual average and the variability of $\mathrm{EQ}$, offers a broad presentation regarding the respect of zonality principle. Thus, this index in the south of the country is higher than in the north of the country. Also in the south of the country, the most essential values are observed (71.7) compared to the rest of the territory. The evolution of the EQ coefficient indicates that in the last two decades, everywhere, its values increase, and in some years, taken separately, the values can far exceed the multiannual average. In the near future, under the action of climate change, the southern region of the country will feel the most intense impact of drying, which will influence and the survival of the oak species in these areas (Nedealcov M. et. al. 2018).

For the investigated areas, Quercus robur and Q,petraea develop under climatic conditions, expressed by the following EQ values: "Plaiul Fagului" Nature Reserve - 32.0-36.0; and the "Codrii" Nature Reserve - 32.0-38.0, which is characteristic for the development of mesophilic oak forests (Fig. 2c).

If we compare the EQ reference values (Ellenberg, H. 1988) with those obtained in our studies, we deduce that from the temperate deciduous forests (which were and still are specific to the study region), in the near future, under the influence of the climate's aridization, we will move to specific climatic conditions, with the growth and development of arid oak forests, with thermophilic species. Their distribution will depend on the distribution at certain hypsometric levels, slopes and exposures and the ability to adapt to the new environmental conditions.

The representation of the vulnerability of some native species to the climate aridization included the mapping of climate beech tolerance index - Q $_{\text {BTI. }}$ 

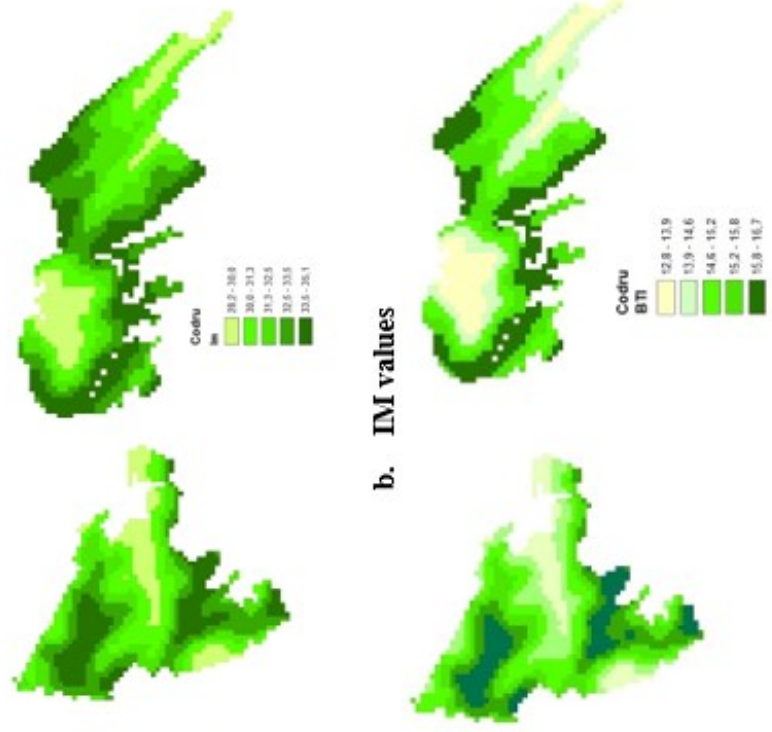

I.Imin

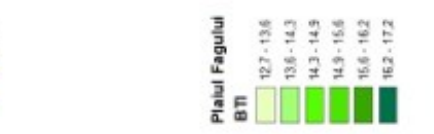

尊

d
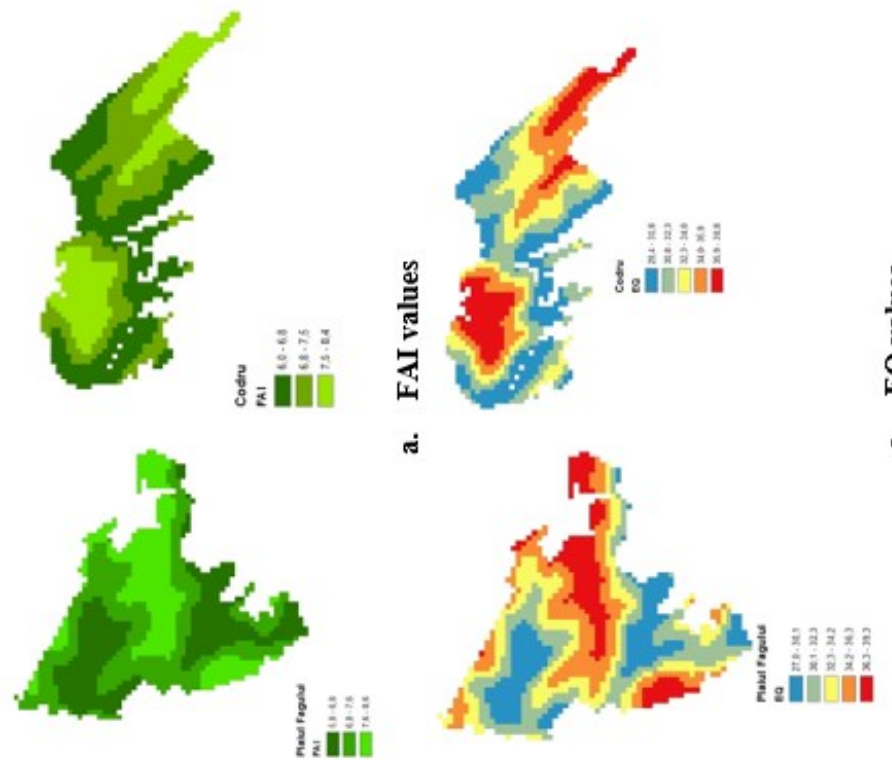

要 
Although Fagus sylvatica is one of the dominant tree species' in central European temperate forests, with high physiological tolerance and competitiveness, drought sensitivity is assumed to be a key factor limiting growth and distribution of beech_near to its lower distributional limit (xeric limit) in southern and south-eastern Europe (Stojanovic et al., 2013, Houston Durrant et al., 2016, Stjepanovic et al., 2018). Studies suggest, also, a decline in beech regeneration or extensive beech dieback with worsening climatic conditions (Rasztovits, 2011).

The temporal QBTI estimation for the Republic of Moldova territory, idicates that Fagus sylvatica develops under climatic conditions expressed by the multiannual average of this index equal to 14.9 units. Values below 10.8 (representing the climate tolerance of beech to drought conditions, according to the data in the literature), in the last period of time, correspond to the drought years $2000,2003,2007,2009,2012,2015$, when the values of this index has dropped substantially below this limit - 2012, 2015 years (Nedealcov M. et. al., 2019).

For the studied areas (Fig. 2d) it was determined that Fagus sylvatica occupied areas that have QBTI values between 15.0 and 17.2 units; under 15.0 units are spread regions with climatic conditions favorable for the development of more resistant species to the water deficit / drought during the vegetation period (included Quercus sp).

\section{Conclusions}

The mesophilic oaks species, adapted to the forest-steppe climatic conditions, will be vulnerable / susceptible to the future climate aridizations, the vulnerability being according to the character, the magnitude and the rate of the climatic variation to which the ecosystems will be exposed, their sensitivity and their adaptive capacity. The estimation of the mesophilic tree species exposure to the regional climate aridization was obtained by using of ecometric indices: Forest Aridity Index (FAI), DeMartonne Aridity Index (IM), Ellenberg Quotient (EQ) and beech tolerance index $\left(\mathrm{Q}_{\mathrm{BтI}}\right)$. For the areas occupied by the oak stands there were indicated values of IM between 30.0-33.0 (medium level of forest vulnerability to drought); of FAI equal to 6.8-8.6 (which allows the development of mesophilic and arid oak forests); EQ values between 32.0-36.0 (specific for mesophilic oak forest development); with QBTI values about 15.0 units for areas with oaks.

In the more arid conditions of the climate, during the vegetation period of the mesophilous deciduous trees from the central part of the Republic of Moldova, with the modification of oaks sensitivity to the water deficit, there will be changes in the compositional structure of the ecosystems and chorological movements of 
the species. The results of the study are of particular interest in the sustainable management of the national forestry sector.

\section{References:}

1. Apostol, L., Nedealcov, Maria, Bojariu, Roxana (2018), Considerații asupra uscăciunii, secetelor și aridității între Carpații Orientali și Nistru, Lucr. Conf. națională „Mediul și dezvoltarea durabilă, Ediția a IV-a, Facultatea de Geografie, Univ. din Tiraspol cu sediul în Chișinău.

2. De Martonne E. (1926). Une nouvelle fonction climatologique. L'indice d'aridite. La Meteorologie: $449-458$.

3. Donica A., Jechiu I. (2019). Aspecte corologice ale speciilor de stejari (quercus robur, q.petraea, q. pubescens) pe teritoriul Republicii Moldova. Culegerea de articole dedicată dlui Andrei Ursu academician AȘM la 90 ani de la naștere și 70 ani de activitate științifică: Starea actuală a componentelor de mediu. Chișinău. P. 244.

4. Ellenberg, H. (1988). Vegetation Ecology of Central Europe. Fourth ed. Cambridge University Press, Cambridge.

5. Fuhrer E. Horvath L., Jagodics A., Machon A., Szabados I. (2011). Application of new aridity index in Hungarian forestry practice. Idojaras, Quarterly Journal of the Hungarian Meteorological Service. Vol. 115, No. 3. pp. 205-216.

6. Houston Durrant T., de Rigo D., Caudullo G. (2016) Fagus sylvatica and other beeches in Europe: distribution, habitat, usage and threats. In: European Atlas of Forest Tree Species. Publ. Off. EU, Luxembourg.

7. Mátyás C., Sun G.(2014). Forests in a water limited world under climate change Environmental Research Letters, Vol. 9, N-8, IOP Publishing Ltd. p.1-10. DOI: 10.1088/1748-9326/9/8/085001

8. Nedealcov M, Dediu I, Donica A, Grigoraș N. (2016). Utilizarea indicelui de ariditate forestier (FAI) pe teritoriul Republicii Moldova. În: Conf. șt. inter., "Biodiversitatea în contextul schimbărilor climatice”. AȘM, Univer. Academ. de Științe a Moldovei, Chișinău, 230-233.

9. Nedealcov M., Grigoraș N. (2017). Analiza temporală a indicelui Martonne pe teritoriul Republicii Moldova. În: Materialele conferinței cu participare internaţională a Societății Naționale a Moldovei de Știința Solului „Cercetarea și gestionarea resurselor de sol". Chișinău. p. 346-353.

10. Nedealcov M., Donica A., Grigoraș N. (2018). Influența condițiilor climatice în distribuția ecosistemelor silvice (studiu de caz). Conferința științifică internațională „Biodiversitatea în contextul schimbărilor climatice”, ediția a II-a. Chișinău. P. 280 283. ISBN 978-9975-108-44-7.

11. Nedealcov, Maria, Răileanu, V., Apostol, L., Adamenko, Tatiana (2018), Podișul Moldovei estimat sub aspect climatic in baza SIG, Akademos, no. 3, Academia de Științe a R. Moldova, Chișinău. 
12. Nedealcov M., Donica A. (2019). Climate limitations of the beech (Fagus sylvatica) within the Republic of Moldova territory. International Journal of Ecosystems and Ecology Science (IJEES), Volume 9/3. P 461-468.

13. Postolache Gh. (2000) Ecosistemele naturale. Vulnerabilitatea şi adaptarea la schimbarea climei. În: Schimbarea climei cercetări, studii, soluţii culegere de lucrări. "Bons Offices" S.R.L., Chișinău, pp.42-48.

14. Rasztovits E. (2011). Modelling the future distribution of beech at lowelevation xeric limits - comparison of empirical and stochastic models. Doctoral (PhD) Dissertation. University of West Hungary Faculty of Forestry Pál Kitaibel Doctoral School of Environmental Sciences, Sopron.

15. Stjepanović S., Matović B., Stojanović D., Lalic B., Levanic T., Orlović S., Gutalj M. (2018). The Impact of Adverse Weather and Climate on the Width of European Beech (Fagus sylvatica L.) Tree Rings in SE Europe. Atmosphere, 9(11), 451. https://doi.org/10.3390/atmos9110451

16. Stojanović D., Kržič A., Matović B., Orlović S., Duputié A., Djurdjević V., Galić Z., Stojnic S. (2013). Prediction of the European beech (Fagus sylvatica L.) xeric limit using a regional climate model: An example from southeast Europe. Agricultural and Forest Meteorology. 176. 94-103. 10.1016/j.agrformet.2013.03.009.

17. (2008). Impacts of Climate Change on European Forests and Options for Adaptation. AGRI-2007-G4-06 Report to the European Commission Directorate-General for Agriculture and Rural Development. 173 p.

18. (2010) Ecosistemele: evaluarea vulnerabilității, impacturile. Schimbările climatice și măsuri de adaptare. Raport Naț. al Dezvoltării Umane 2009-2010. UNDP, p.66-78.

19. (2011). Raport privind starea sectorului forestier din Republica Moldova: perioada 2006-2010. Agenția "Moldsilva", Chișinău. 48 p.

20. (2014) Republica Moldova - Notă de politici forestiere, , Banca Internațională pentru Reconstrucție și Dezvoltare, Chișinău.

21. (2014). Integrated Drought Management Programme in Central and Eastern Europe. Assessment of drought impact on forests. Milestone no.3. Elaboration of maps for current climate, 2050 and 2070 in Bulgaria, Lithuania, Slovenia and Ukraine (pilot area) and determination of forest vulnerability zones. Global Water Partnership. Central and Eastern Europe (GWP CEE). Regional Secretariat. Slovak Hydrometeorological Institute. Bratislava, Slovakia. www.gwpceeforum.org

22. (2014). Strategia Republicii Moldova de adaptare la schimbarea climei până în anul 2020 şi a Planul de acţiuni pentru implementarea acesteia nr. 1009 din 10.12.2014. Monitorul Oficial nr.372-384/1089 din 19.12.2014

2020 by the authors. Licensee UAIC, Iasi, Romania. This article is an open access article distributed under the terms and conditions of the Creative Commons Attribution (CC BY-NC-ND) license (https:// creativecommons.org/licenses/by-nc-nd/4.0). 